September 2012

\title{
Complete Preemption and Copyright: Toward a Successive
}

\section{Analysis}

Mark Lindsay

Follow this and additional works at: https://digitalcommons.law.uga.edu/jipl

Part of the Courts Commons, and the Intellectual Property Law Commons

\section{Recommended Citation}

Mark Lindsay, Complete Preemption and Copyright: Toward a Successive Analysis, 20 J. INTELL. PROP. L. 43 (2012).

Available at: https://digitalcommons.law.uga.edu/jipl/vol20/iss1/3

This Article is brought to you for free and open access by Digital Commons @ University of Georgia School of Law. It has been accepted for inclusion in Journal of Intellectual Property Law by an authorized editor of Digital Commons @ University of Georgia School of Law. Please share how you have benefited from this access For more information, please contact tstriepe@uga.edu. 


\title{
COMPLETE PREEMPTION AND COPYRIGHT: TOWARD A SUCCESSIVE ANALYSIS
}

\author{
Mark Lindsay*
}

\section{TABLE OF CONTENTS}

I. INTRODUCTION .

II. WHY PRACTITIONERS BATTLE OVER FORUM: PlAINTIFFS PREFER STATE COURT, AND DEFENDANTS PREFER FEDERAL COURT .............49

A. PLAINTIFFS PREFER STATE COURT …...............................................50

B. DEFENDANTS PREFER FEDERAL COURT …........................................50

C. NOTICE OF REMOVAL TO FEDERAL COURT .....................................51

D. MOTIONS TO REMAND TO STATE COURT ........................................52

III. REMOVAL OF COPYRIGHT-RELATED CASES AND THE COMPLETE PREEMPTION DOCTRINE: THE DOCTRINE AND THE DEBATE............52

A. COMPLETE PREEMPTION VERSUS ORDINARY PREEMPTION ..........52

1. Ordinary Preemption........................................................................52

2. Two Types of Ordinary Preemption Exist............................................53

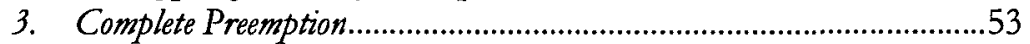

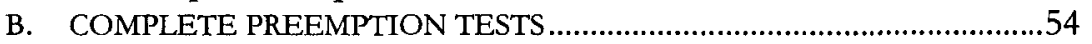

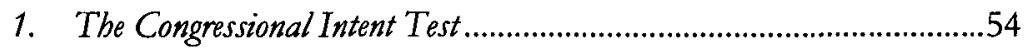

2. The Exclusive Federal Cause of Action Test.......................................54

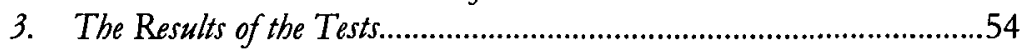

a. The Complete Preemption Doctrine Applies.................................55

b. The Complete Preemption Doctrine Does Not Apply.....................55

C. THE DEBATE OVER COMPLETE PREEMPTION.....................................55

1. Perspectives on Complete Preemption in General..................................56

2. Perspectives on the Tests ..................................................................57

a. Views on the Congressional Intent Test.......................................57

b. Views on the Exclusive Federal Cause of Action Test...................58

c. Improvements to the Tests ..........................................................59

3. Complete Preemption and the Copyright Act ......................................60

a. The Congressional Intent Test and the Copyright Act ...................60

b. The Exclusive Federal Cause of Action Test and the Copyright Act..

* J.D., Georgia State University College of Law, 2003; B.A., University of Toronto, 2000. 
Journal of Intellectual Property Law, Vol. 20, Iss. 1 [2012], Art. 3

44

c. The Two-Prong Test of Subject Matter and General Scope............61

d. The Results of the Two-Prong Test................................................63

e. Views on Complete Preemption in the Copyright Act Context ......64

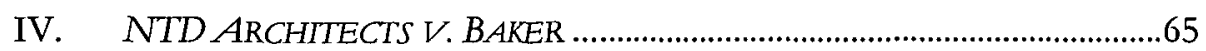

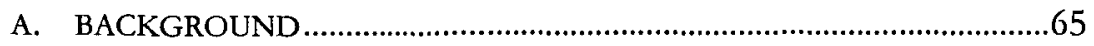

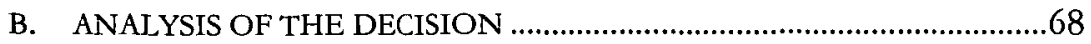

1. The Complete Preemption Doctrine ....................................................68

2. The Congressional Intent Test and the Exclusive Federal Cause of Action Test........................................................................................69

3. The Two-Prong Test of Subject Matter and General Scope ....................71

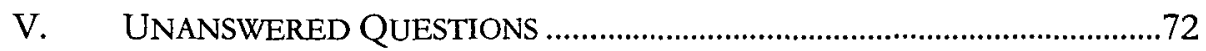

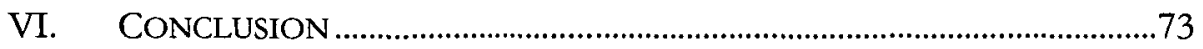


District courts in most circuits face a problem: does the socalled "complete preemption" doctrine apply to the Copyright Act-that is, does the complete preemption doctrine allow a defendant to remove a case that states only state law claims from state court to federal court if the Copyright Act seems to cover the subject matter of the claims? This Article proposes that courts and practitioners need to start arguing the merits of both the complete preemption doctrine and the tests that apply to the doctrine-the congressional intent test, the exclusive federal cause of action test, and the extra element test.

Commentators and courts disagree on the merits of using the complete preemption doctrine in context of the Copyright Act. Plaintiffs prefer state courts, and defendants prefer federal courts. Therefore, defendants often remove cases to federal courts, and plaintiffs move to remand cases to state courts. In cases that involve copyrights, sometimes plaintiffs file cases in state courts and omit claims of copyright infringement to avoid federal court jurisdiction, while defendants increasingly assert that causes of action of breach of contract claims and other claims that involve copyrights relate to the Copyright Act. Thus, the complete preemption doctrine allows the defendant to remove the case to federal court. The competing views of commentators and courts inform plaintiffs and defendants sufficiently to allow them to argue the merits of each step of the analysis.

\section{INTRODUCTION}

In three situations, a defendant in a state court may transfer the lawsuit to a federal court. When a plaintiff files a lawsuit in state court that presents a question of federal law or involves parties who reside in different states, the defendant may file a notice of removal in the state court and another notice of removal in. a federal court to transfer the case from the state court to the federal court. ${ }^{1}$ In a third situation, if a plaintiff files a lawsuit in state court that presents a question of state law and neither presents a question of federal law nor involves parties who reside in different states, the doctrine of "complete preemption" allows the defendant to transfer the case to a federal court, if a federal statute completely encompasses the subject matter of the state law. ${ }^{2}$

128 U.S.C. \$1441(a) (2006); 28 U.S.C. $\$ 1446$ (2006).

2 See Avco Corp. v. Aero Lodge No. 735, Int'l Ass'n of Machinists, 390 U.S. 557 (1968) (applying the complete preemption doctrine); Metro. Life Ins. Co. v. Taylor, 481 U.S. 58 (1987) 
The federal courts do not agree on whether the doctrine of complete preemption applies to the Copyright Act--that is, whether the Copyright Act so completely covers the field of copyright law that a defendant may remove a lawsuit that presents questions of state law that involve copyright-protected material. ${ }^{3}$ The Courts of Appeals for the Second, Fourth, and Sixth Circuits have held that the Copyright Act (the Act) ${ }^{4}$ completely blankets the field of copyright law. ${ }^{5}$ Thus, in these circuits, the doctrine of complete preemption allows a defendant to remove a case from a state court to a federal court if the plaintiff presents a question of state law that the Copyright Act covers. ${ }^{6}$ The 'Third Circuit has held that the Copyright Act does not completely blanket the field of copyright law. ${ }^{7}$ In the remaining circuits, a problem faces the district courts: should the doctrine of complete preemption apply to the Copyright Act to allow defendants to transfer cases from state court to federal court?8

Part I of this Article addresses the battle that ensues when defendants try to transfer a case from state court to federal courts. It also discusses that plaintiffs tend to prefer state court and addresses the reasons that motivate plaintiffs to file cases in state court. Part I also addresses defendants' preference for federal courts as well as the factors that animate this preference. Defendants often try to transfer lawsuits from state court to federal court, and the considerations that these defendants must take into account are discussed.9 Similarly, a plaintiff usually attempts to return a case to state court if the defendant successfully

(same); Beneficial Nat'l Bank v. Anderson, 539 U.S. 1 (2003) (same).

3 See, e.g., Ritchie v. Williams, 395 F.3d 283 (6th Cir. 2005) (finding complete preemption doctrine applies to the Copyright Act); Bd. of Chosen Freeholders v. Tombs, 215 F. App'x 80 (3d Cir. 2006) (finding complete preemption doctrine does not apply to the Copyright Act).

417 U.S.C. \$ 301 (a) (2006).

5 Briarpatch Ltd. v. Phoenix Pictures, Inc., 373 F.3d 296 (2d Cir. 2004); Rosciszewski v. Arete Assocs., 1 F.3d 225 (4th Cir. 1993); Ritchie, 395 F.3d at 287.

6 See, e.g., Briarpatch, 373 F.3d at 309 (finding that the complete preemption doctrine applies to the Copyright Act and denying motion to remand).

7 Tombs, 215 F. App'x at 82.

8 See, e.g., Black v. Kos, No. CIV 05-163, 2005 WL 4564587, at *1 (D.N.M. Mar. 29, 2005) (holding complete preemption doctrine does not apply to the Copyright Act); Crooks v. Certified Computer Consultants, 92 F. Supp. 2d 582, 587 (W.D. La. 2000) (finding that the complete preemption doctrine does not apply to the Copyright Act); Am. Airlines v. Biztraveldeals.com, No. 4:08-CV-069-A, 2008 WL 818536, at *3 (N.D. Tex. Mar. 26, 2008) (holding that the complete preemption does not apply to the Copyright Act); W. States Pathology, Inc. v. Ruffdogs, Inc., No. 06-cv-02473-PSF-MJW, 2007 WL 196839, at *2 (D. Colo. Jan. 19, 2007) (applying the complete preemption doctrine to the Copyright Act); Mattel, Inc. v. Bryant, $441 \mathrm{~F}$. Supp. 2d 1081, 1092 (C.D. Cal. 2005) (finding that the complete preemption applies to the Copyright Act).

9 Casey Tourtillott \& Matt Corbin, A Practitioner's Road Map to Removal and Remand in Kansas Courts, 76 J. KAN. B.A., no. 9, Oct. 2007, at 22. 
transferred the case to federal court, and the battle that ensues between the plaintiff and defendant is addressed. ${ }^{10}$

Part II addresses the field of battle in a growing number of cases: whether the Copyright Act so completely covers the subject matter of the questions of state law in a lawsuit that the doctrine of complete preemption allows the defendant to transfer the lawsuit to federal court. The doctrine of complete preemption and the difference between complete preemption and the defense of ordinary preemption are explained."1 Part II then illustrates the arguments of scholars and courts in favor and against the doctrine of complete preemption. ${ }^{2}$ Although the Supreme Court has applied the doctrine to the Employee Retirement Income Security Act, ${ }^{13}$ the Labor Management Relations Act, ${ }^{14}$ and the National Bank Act; ${ }^{15}$ and some circuit courts have extended the doctrine to the other statutes, ${ }^{16}$ including the Copyright Act, ${ }^{17}$ many scholars criticize the doctrine as a whole and the jurisprudence of the Supreme Court. ${ }^{18}$ Thus, in most circuit courts, judges must decide whether to apply the controversial doctrine to the Copyright Act. Part II sets out the arguments in favor and against the doctrine in the copyright context.

The Ninth Circuit has not decided whether the doctrine applies to the Copyright Act. ${ }^{19}$ However, recently, the United States District Court for the Southern District of Southern California decided a case that demonstrates the complexity of the complete preemption doctrine in the copyright context. ${ }^{20}$ NTD Architects, an architectural firm in San Diego, sued two former employee

\footnotetext{
10 Id.

11 14B Charles Alan Wright, Arthur R. Miller \& Edward H. CoOper, Federal PRACTICE AND PROCEDURE: JURISDICTION $\$ 3722.2$ (4th ed. 2012).

12 See, e.g., Gil Seinfeld, The Purzle of Complete Preemption, 155 U. PA. L. REV: 537 (2007); Paul E. McGreal, In Defense of Complete Preemption, 155 U. PA. L. REV. PENNuMBRA 147 (2007).

13 Metro. Life Ins. Co. v. Taylor, 481 U.S. 58, 66-67 (1987).

14 Avco Corp. v. Aero Lodge No. 735, Int'l Ass'n of Machinists \& Aerospace Workers, 390 U.S. 557, 560 (1968).

15 Beneficial Nat'l Bank v. Anderson, 539 U.S. 1, 10-11 (2003).

16 See, e.g., Trans World Airlines, Inc. v. Mattox, 897 F.2d 773 (5th Cir. 1990) (finding that the complete preemption doctrine extends to the Federal Aviation Act); Bastien v. AT\&T Wireless Servs., Inc., 205 F.3d 983 (7th Cir. 2000) (holding that the complete preemption doctrine applies to the Federal Communications Act).

17 See, e.g., Briarpatch Ltd. v. Phoenix Pictures Inc., 373 F.3d 296, 309 (2d Cir. 2004) (finding that the complete preemption doctrine extends to the Copyright Act).

18 See, e.g., Trevor W. Morrison, Complete Preemption and the Separation of Powers, 155 U. PA. L. REV. PENNUMBRA 186 (2007).

19 Dielsi v. Falk, 916 F. Supp. 985, 993 (C.D. Cal. 1996) ("[T]here is no Ninth Circuit authority on point.").

20 NTD Architects v. Baker, No. 12-CV-0020-AJB-JMA, 2012 WL 2498868 (S.D. Cal. June 27, 2012).
} 
architects in San Diego Superior Court and asserted eight state law claims, including misappropriation of trade secrets, breach of fiduciary duty, conversion, and intentional interference with prospective economic advantage. ${ }^{21}$ The architects, Jon Baker and Richard Nowicki, removed the case to the United States District Court for the Southern District of California, and NTD Architects filed a motion to remand the lawsuit to the San Diego Superior Court on the grounds that the Southern District of California did not have jurisdiction. 2

Baker and Nowicki opposed the motion to remand on the grounds that the Copyright Act completely preempted the state law claims because the Copyright Act broadly covered the field of copyright law and the claims concerned copyright-protected material, such as computer files. ${ }^{23}$ The Southern District of California agreed with arguments of Baker and Nowicki and concluded that the doctrine of complete preemption applied to the Copyright Act.24 The court decided that the Copyright Act preempted the conversion claim and therefore that Baker and Nowicki properly removed the lawsuit.25

Part IV of this Article examines the decision of the Southern District of California. Some scholars dislike the doctrine of complete preemption because it increases the caseload of federal courts. ${ }^{26}$ Part IV examines whether the court adequately considered this argument and other arguments. The court ultimately decided that the doctrine rests on solid footing and assessed whether to apply the doctrine to the Copyright Act. ${ }^{27}$ Courts use one of two tests to decide whether to extend the doctrine to the Copyright Act: the older "congressional intent" test ${ }^{28}$ or the newer "exclusive federal cause of action" test. ${ }^{29}$

In this case, the court examined whether Congress intended the Copyright Act to cover copyright law so broadly that the Act would preempt similar

21 Id. at $* 1$.

22 Id. at $* 1-2$.

23 Defendants' Opposition to Plaintiff's Motion to Remand to State Court Pursuant to 28 U.S.C. $\$ 1147$ (c), NTD Architects v. Baker, No. 12-CV-0020-AJB-JMA (S.D. Cal. Feb. 22, 2012).

24 NTD Architects, 2012 WL 2498868, at *4-6.

25 Id. at $* 8$.

26 E.g., Eric James Moss, The Breadth of Complete Preemption: Limiting the Doctrine to its Roots, 76 VA. L. REV. 1601, 1638 (1990).

27 NTD Architects, 2012 WL 2498868, at *4.

28 See, e.g., Rosciszewski v. Arete Assocs., 1 F.3d 225, 231 (4th Cir. 1993) (" $\Pi n$ deciding whether the preemptive force of the Copyright Act is so extraordinary that a state-law claim ... becomes federal in nature, the focus of our inquiry must be congressional intent.").

29 See, e.g., Briarpatch Ltd. v. Phoenix Pictures Inc., 373 F.3d 296, 305 (2d Cir. 2004) (holding that the complete preemption doctrine extends "to any federal statute that both preempts state law and substitutes a federal remedy for that law, thereby creating an exclusive federal cause of action"). 
causes of action under state law, allowing defendants to remove cases to federal court. ${ }^{30}$ The Court found that Congress expressed this kind of intent in two provisions. ${ }^{31}$ Part IV assesses whether the court correctly decided to use the older congressional intent test and the effect of this decision on the evolution of the complete preemption doctrine. Part IV also evaluates whether Congress intended the Copyright Act to play the role of a completely preemptive statute. Finally, Part IV addresses whether the court correctly decided that the Copyright Act completely preempted the conversion claim.

The court's opinion leaves many other questions unanswered, and Part V address these questions. The court decided that the Copyright Act did not completely preempt the other seven claims;32 it did not, however, provide a detailed explanation for this decision. ${ }^{33}$ Why did the court find that the Copyright Act does not completely preempt a misappropriation of trade secrets claim? ${ }^{34}$ Why did the court find that the Act does not completely preempt a breach of fiduciary duty claim?35 Part V assesses these and other questions in light of the competing arguments of scholars and other courts and attempts to provide guidance to practitioners.

\section{WHY PRACTITIONERS BATTLE OVER FORUM: PLAINTIFFS PREFER STATE COURT, AND DEFENDANTS PREFER FEDERAL COURT}

Plaintiffs and defendants prefer different courts. Plaintiff's counsel usually feels more comfortable with state court procedures. ${ }^{36}$ Defendant's counsel often believes that federal courts have more expertise in federal copyright law. ${ }^{37}$ Thus, defense lawyers often try to remove the case to a federal court and must consider several factors. The plaintiff's lawyer then usually attempts to remand the case to state court.

\footnotetext{
30 NTD Architects, 2012 WL 2498868, at *5-6.

31 Id.

32 Id. at $* 8$.

33 Id.

34 Id. (finding misappropriation of trade secrets claim "not preempted by the Copyright Act").

35 See id. (finding breach of fiduciary duty claim "not preempted by the Copyright Act").

36 Tourtillott \& Corbin, supra note 9, at 22; Howard B. Stravitz, Recocking the Removal Trigger, 53 S.C. L. REV. 185, 185 (2002).

37 See Deborah Pearce Reggio, Removal and Remand: A Guide to Navigating Between the State and Federal Courts, 23 MIss. C. L. REV. 97, 97-99 (2004) (observing that removal "ensures that the better-informed tribunal adjudicates questions of federal law. . . While fear of local prejudice and the notion that state judges are not competent to adjudicate federal questions originally drove defendants to remove cases, in modern times, removal is driven more by strategic concerns.").
} 
Practitioners who handle cases that involve copyright-protected material know that "the stakes involved in removal are high." 38 In federal court cases that involve copyright law, the "Copyright Act permits attorney's fees to be awarded to the prevailing party." 39

\section{A. PLAINTIFFS PREFER STATE COURT}

Plaintiffs' lawyers prefer state courts to federal courts for several reasons. They usually feel more competent in state court procedure.40 Also, they sometimes believe that federal judges express apathy toward plaintiffs. ${ }^{41}$ Many lawyers assert that federal courts favor defendants, especially as federal expert witness rules tend to weigh in a defendant's favor. ${ }^{42}$ If a plaintiff's lawyer believes that the defendant may attempt to remove a case in state court to a federal court, then the lawyer normally files the suit in a state court in a federal district that tends to interpret the removal rules in favor of the plaintiff.

Unfortunately, many cases that involve copyright-protected material present questions of federal law.43 Consequently, "for strategic reasons, occasionally plaintiffs bring state law causes of action in state court that, in reality, arise exclusively under the Copyright Act, in an attempt to keep the case out of federal court." 4

\section{B. DEFENDANTS PREFER FEDERAL COURT}

In cases that involve copyrights and other cases, defendants prefer federal courts for several reasons. Sometimes out-of-state defendants remove cases to federal courts because they fear that the state court clings to bias in favor of local citizens. ${ }^{45}$ Further, defendants often remove cases to federal courts to counteract all of the above-mentioned factors that cause plaintiffs to file

\footnotetext{
38 RAYMond J. DOWD, Copyright Litigation HANDBOOK $₫ 10: 2$ (2009).

39 Id.

40 Tourtillott \& Corbin, supra note 9, at 22; Stravitz, supra note 36, at 185.

41 Kevin M. Clermont \& Theodore Eisenberg, Do Case Outcomes Really Reveal Anything About the Legal System? Win Rates and Removal Jurisdiction, 83 CORNELL L. REv. 581, 601 (1998).

42 Thomas A. Mauet, The New World of Experts in Federal and State Courts, 25 AM. J. TriaL ADVoc., no. 2, Fall 2011, at 234-35; Heather R. Barber, V. Removal and Remand, 37 LOY. L.A. L. REV. 1555, 1555 (2004).

43 DowD, supra note 38; see, e.g., Rosciszewski v. Arete Assocs., 1 F.3d 225, 229-33 (4th Cir. 1993) (involving copyright protected computer program).

445 WILLIAM F. PATRY, PATRY ON COPYRIGHT $\$ 17: 23$ (2012).

45 Tourtillott \& Corbin, supra note 9 , at 22.
} 
lawsuits in state court. 46 Indeed, defendants regularly remove cases to take the plaintiff to the less familiar forum of federal court. ${ }^{47}$

Defendants also feel that federal judges are better informed;48 specifically, defendants value federal court judges' expertise in cases that present questions of federal law.49 Furthermore, some lawyers believe that federal courts favor defendants' motions for summary judgment more than plaintiffs'. ${ }^{50}$

\section{NOTICE OF REMOVAL TO FEDERAL COURT}

Although federal courts provide several advantages to defendants, defendants must consider several factors when evaluating whether to remove a case to federal court. ${ }^{51}$ Deborah Pearce Reggio has outlined these considerations. 52

First, defendants must consider the jury. ${ }^{53}$ Specifically, defendants must consider "the geographic scope of the pools, the number of jurors required to reach a verdict, and the rules governing jury demand in each forum." ${ }_{54}$ Second, defendants must consider the rules of civil procedure.55 Defendants must evaluate their "familiarity with the respective procedural rules, the time frame and production requirements of each court, each court's general treatment of motion practice, and the various disclosure and discovery rules." 56 Third, defendants must consider the judge. ${ }^{57}$ Specifically, defendants must consider the caseloads of the available judges, the familiarity of the judges with files, the circumstances of the appointments of judges, and the rules that govern the removal of judges; these factors impact the advantages of the assigned judge.58

\footnotetext{
46 See Clermont \& Eisenberg, supra note 41, at 598 (finding that removal lowers the win rate of the plaintiff).

47 See id. at 599 (observing that removal "dislodg[es]" the plaintiff from a familiar forum and "revers[es] the ... differences in procedural law that led the plaintiff to prefer state court").

48 Reggio, supra note 37 , at 97.

49 Id.

50 Stravitz, supra note 36 , at 185 n.1.

51 Reggio, supra note 37, at 98.

52 Id.

53 Id.

54 Id. (quoting Hon. William W. Schwarzel ét AL., Federal Civil Procedure Before TRIAL [2:576-87.1, 2:597]).

$\begin{array}{ll}55 & I d . \\ 56 & I d . \\ 57 & I d . \\ 58 & I d .\end{array}$
} 


\section{MOTIONS TO REMAND TO STATE COURT}

If a defendant considers all of the above-mentioned factors and decides to remove a case to federal court, then the plaintiff typically files a motion to remand the case to state court. The ensuing battle sometimes lasts years..$^{59}$ The delay helps defendants, buying more time to build their defense.60 Consequently, if a plaintiff files a case in a state court, the defendant oftentimes removes the case to a federal court.

Statistics support the frequency and efficacy of removal. ${ }^{61}$ Removal transfers about thirty thousand state court cases to federal courts in a year and generates $12 \%$ of the cases in federal courts.62 Further, statistics show that plaintiffs' win rate in federal court drops if the defendant removed the case from state court. ${ }^{63}$ Hence, the battle of forum deserves the close attention of plaintiffs and defendants.

\section{REMOVAL OF COPYRIGHT-RELATED CASES AND THE COMPLETE PREEMPTION DOCTRINE: THE DOCTRINE AND THE DEBATE}

Defendants in cases that involve copyrights remove cases to federal court in three circumstances.64 First, if the case presents a question of federal law, then 28 U.S.C. $\$ 1441(\mathrm{a})-(\mathrm{b})$ allows the defendant to remove the case to federal court. ${ }^{5}$ Second, if the case involves parties who reside in different states, 28 U.S.C. $\ 1441$ allows the defendant to remove the case. Third, if the plaintiff presents state law claims that the Copyright Act completely preempts, then the doctrine of complete preemption allows the defendant to remove the case to federal court.66

\section{A. COMPLETE PREEMPTION VERSUS ORDINARY PREEMPTION}

1. Ordinary Preemption. Ordinary preemption refers to a defense.67 When a plaintiff files a lawsuit that includes a state law claim, ordinary preemption

\footnotetext{
59 Barber, supra note 42 , at 1558.

60 Id.

61 Carol E. Heckman, Removal Jurisdiction: A Trap for the Unwary: Outside Counsel, N.Y. L.J., Sept. 11,2000 , at 1

62 Id.

63 Clermont \& Eisenberg, supra note 41, at 593.

6428 U.S.C. $\$ 1441$ (a)-(d); Briarpatch, 373 F.3d at 305.

6528 U.S.C. $\$ 1441(\mathrm{a})-(\mathrm{b})$.

66 Briarpatch Ltd. v. Phoenix Pictures Inc., 373 F.3d 296, 305 (2d Cir. 2004).

67 14B WRIGHT, MILIER \& COOPER, supra note 11.
} 
authorizes the defendant to assert in defense that the state law conflicts' with a federal law. ${ }^{68}$ If the court agrees, it dismisses the state law claim. ${ }^{69}$

2. Two Types of Ordinary Preemption Exist.70 "Express preemption" means that a federal statute states that it overrides similar state laws." "Implied preemption" signifies that the federal law does not plainly say that it overrides similar state laws.72 Both express preemption and implied preemption provide defenses to a defendant, ${ }^{73}$ but they do not allow a defendant to remove a case in a state court to a federal court. ${ }^{74}$

3. Complete Preemption. Complete preemption, however, empowers a defendant to remove a case from state court to federal court. ${ }^{25}$ The removal statute generally allows a defendant to transfer a case from state court to a federal court if it raises a federal claim" 7 -the "well-pleaded" complaint rule provides that the plaintiff's complaint must expressly present a federal question to allow the defendant to remove the case. Thus, a plaintiff who files a lawsuit that relies exclusively on state law generally prevents removal of the case..$^{77}$ The doctrine of complete preemption, however, provides an exception or corollary to this rule..$^{78}$ If the complaint includes a state law claim and a federal statute extraordinarily broadly covers the subject matter of the state law claim, then the doctrine allows the defendant to remove the entire lawsuit to a federal court.79 The doctrine essentially converts the state law complaint into a complaint that states a question of federal law. .80

${ }^{68}$ See $14 \mathrm{~B} i d$. ("P]reemption ordinarily cannot serve as a basis for removal because it is raised as a defense.").

69 See id. ("If a plaintiff's state law claim is deemed preempted by federal law, the state law claim is simply dismissed.").

70 See Elizabeth Helmer, The Ever-Expanding Complete Preemption Doctrine and the Copyright Act: Is This What Congress Really Wanted?, 7 N.C. J.L. \& TECH. 205, 207 (2005) ("A claim may be preempted expressly or impliedly.").

71 Id.

72 Id.

73 14B WRIGHT, MILLER \& COOPER, supra note $11, \S 3722.2$.

74 14B id.

75 Briarpatch, 373 F.3d at 305.

7628 U.S.C. $\$ 1441$ (a).

77 14B WRIGHT, MILIER \& COOPER, supra note $11, \S 3722.2$.

78 Paul E. McGreal, In Defense of Complete Preemption, 156 U. PA. L. REv. PENNumBRa 147, $147-$ 48 (2007).

79 See Beneficial Nat'l Bank v. Anderson, 539 U.S. 1, 6-8 (2003) (holding that "a state claim may be removed to federal court ... when a federal statute wholly displaces the state-law cause of action through complete pre-emption").

80 DowD, supra note 38, \$10:6. 
First, a federal statute must extraordinarily broadly cover a field of federal law. If a court determines that this is the case, then the court assesses whether the federal statute covers the subject matter of the state law claim.

\section{B. COMPLETE PREEMPTION TESTS}

To assess whether a federal statute extraordinarily broadly covers a field of federal law, courts apply one of two tests: the "congressional intent" test ${ }^{81}$ or the "exclusive federal cause of action" test. ${ }^{82}$

1. The Congressional Intent Test. In Metropolitan Life Insurance Co. v. Taylor, the Supreme Court created the congressional intent test. ${ }^{83}$ Under the test, a federal statute extraordinarily broadly covers a field of federal law if "Congress has clearly manifested an intent to make causes of action within the scope... [of the statute] removable to federal court." 84

2. The Exclusive Federal Cause of Action Test. Several years later, in Beneficial National Bank v. Anderson, the Supreme Court created the exclusive federal cause of action test. ${ }^{85}$ The test provides that a federal statute extraordinarily broadly covers a field of federal law if the "federal statute ... both preempts state law and substitutes a federal remedy for that law, thereby creating an exclusive federal cause of action." 86 Although the Court decided Anderson in 2003 and Taylor in 1987, some courts still apply the earlier Taylor test of congressional intent. ${ }^{87}$

3. The Results of the Tests. If a defendant removes a case in a state court to a federal court and asserts that the doctrine of complete preemption allows him to remove the case because a federal statute extraordinarily broadly covers a state law claim, then the federal district court applies one of the two tests to determine if the complete preemption doctrine applies to the statute. The Supreme Court has decided that the doctrine applies to the Labor Management Relations Act, ${ }^{88}$ the Employee Retirement Security Act, ${ }^{89}$ and the National Bank

81 See Metro. Life, 481 U.S. at 63-64 (holding that "Congress may so completely pre-empt a particular area that any civil complaint raising this select group of claims is necessarily federal").

82 See Beneficial Nat'l Bank, 539 U.S. at 8 ("[W]here this Court has found complete preemption ... the federal statutes at issue provided the exclusive cause of action for this claim asserted and also set forth procedures and remedies governing that cause of action.").

83 Metro. Life, 481 U.S. at 61-67.

84 Id. at 66.

85 Beneficial Nat'l Bank, 539 U.S. at 8-11.

86 Briarpatch Ltd. v. Phoenix Pictures Inc., 373 F.3d 296, 305 (2d Cir. 2004).

87 See, e.g., Ritchie v. Williams, 395 F.3d 283, 286-87 (6th Cir. 2005) (applying the "congressional intent" test); NTD Architects v. Baker, No. 12-CV-0020-AJB-JMA, 2012 WL 2498868 (S.D. Cal. June 27, 2012) (applying the "congressional intent" test).

88 Avco Corp. v. Aero Lodge No. 735 Int'l Ass'n of Machinists \& Aerospace Workers, 390 
Act.90 The courts of appeals and district courts have applied the two tests and decided that the doctrine applies to some additional statutes and not others.1

a. The Complete Premption Doctrine Applies. Some courts of appeals have held the doctrine applies to the following statutes: the Bankruptcy Code; the Carmack Amendment to the Interstate Commerce Act; the Federal Communications Act; the Federal Railroad Safety Act; the Depository Institutions Deregulation and Monetary Control Act; the Railway Labor Act; the Federal Deposit Insurance Act; the Securities Litigation Uniform Standards Act; the Air Transportation Safety and System Stabilization Act; and the Copyright Act.92

b. The Complete Preemption Doctrine Does Not Apply. Conversely, some courts of appeal have held that the complete preemption doctrine does not apply to the following statutes: the Comprehensive Environmental Response, Compensation, and Liability Act; the Federal Communications Act; the Federal Insecticide, Fungicide, and Rodenticide Act; the Lanham Act; the National Labor Relations Act; and the Copyright Act. ${ }^{33}$ The Second, Fourth, and Sixth Circuits have held that the complete preemption doctrine applies to the Copyright Act, but the Third Circuit has held that the doctrine does not. ${ }^{94}$

\section{THE DEBATE OVER COMPLETE PREEMPTION}

Courts and scholars disagree on many aspects of the complete preemption doctrine in general and the doctrine in the copyright context in particular. Some scholars and judges dislike the doctrine as a whole or one of the tests in particular, while other scholars and judges accept the doctrine and one of the tests. In the copyright context, commentators disagree, while three circuits apply the doctrine to the Copyright Act and one circuit does not.95

\footnotetext{
U.S. 557, 560 (1968).

89 Metro. Life Ins. v. Taylor, 481 U.S. 58, 66-67 (1987).

90 Beneficial Nat'l Bank, 539 U.S. at 10-11.

91 14B WRIGHT, MILLER \& COOPER, supra note 11, \3722.2.

$9214 \mathrm{~B}$ id.

$9314 \mathrm{~B}$ id.

94 See Briarpatch Ltd. v. Phoenix Pictures, Inc., 373 F.3d 296, 305 (2d Cir. 2004) (finding the complete preemption doctrine applies to the Copyright Act); Rosciszewski v. Arete Assocs., 1 F.3d 225, 232-33 (4th Cir. 1993) (finding the complete preemption doctrine applies to the Copyright Act); Ritchie v. Williams, 395 F.3d 283, 287 (6th Cir. 2005) (finding the complete preemption doctrine applies to the Copyright Act); Bd. of Chosen Freeholders v. Tombs, $215 \mathrm{~F}$. App'x 8, 82 (3d Cir. 2006) (finding the complete preemption doctrine does not apply to the Copyright Act).

${ }_{25}$ See Helmer, supra note 70, at 229-31 (arguing that applying the doctrine is eroding federalism); David Ratner, The Ongoing Struggle to Determine Federal "Arising Under" Jurisdiction in Copyright: The Complete Preemption Exception to the Well Pleaded Complaint Rule, 84 DENV. U. L. REV.
} 
Moreover, the four circuits used different tests to determine whether the complete preemption doctrine applies to the Copyright Act-two circuits ${ }^{96}$ applied the congressional intent test, and two circuits ${ }^{97}$ applied the exclusive federal cause of action test-which leaves courts in the remaining circuits with a split of persuasive authority on which test to apply and whether the doctrine applies to the Copyright Act.

Courts and practitioners in most circuits face a problem: does the complete preemption doctrine apply to the Copyright Act? The arguments of commentators and judges provide practitioners with the tools to advocate either that the doctrine applies to the Copyright Act or that it does not. A defendant who seeks to remove a case on the grounds that the complete preemption doctrine applies to the Copyright Act needs to show (1) that the complete preemption doctrine as a whole rests on solid footing, (2) that one of the tests best animates the doctrine, and (3) that the chosen test shows that the doctrine applies to the Copyright Act. ${ }^{98}$ Conversely, a plaintiff who seeks to remand a case to state court needs to show (1) that the doctrine rests on shaky footing, (2) that neither test functions, and that that even if the court still applies the tests, the doctrine does not apply to the Copyright Act..$^{99}$

1. Perspectives on Complete Premption in General. Competing theories explain the legal basis for the complete preemption doctrine.

Judges and commentators disagree on the language of complete preemption. Under one perspective, the complete preemption doctrine provides an "exception"100 to the well-pleaded complaint rule-the well-pleaded complaint rule allows the defendant to remove a case only if the complaint plainly asserts a question of federal law. ${ }^{101}$ Under this perspective, the complete preemption doctrine provides an unwarranted exception to the long-standing rule that a defendant cannot remove a case that merely asserts state law claims. ${ }^{102}$ Under

955, 974-76 (2006) (arguing that applying the doctrine is supporting federalism); see also Briarpatch, 373 F.3d at 305 (applying the doctrine); Rosciszemski, 1. F.3d at 232-33 (applying the doctrine); Ritchie, 395 F.3d at 287 (applying the doctrine); Tombs, 215 F. App'x at 82 (declining to apply the doctrine).

96 See Rosciszenskei, 1 F.3d at 232-33; Ritchie, 395 F.3d at 286-87.

97 See Briarpatch, 373 F.3d at 305; Tombs, 215 F. App'x at 82.

98 See, e.g., Mattel, Inc. v. Bryant, 441 F. Supp. 2d 1081, 1092 (C.D. Cal. 2005) (finding that the complete preemption doctrine applies to the Copyright Act).

99 See, e.g., Crooks v. Certified Computer Consultants, Inc., 92 F. Supp. 2d 582, 587 (W.D. La. 2000) (finding that the complete preemption doctrine does not apply to the Copyright Act).

100 Seinfeld, supra note 12, at 549 ("The complete preemption doctrine is an exception to the [well-pleaded complaint] rule.'); Elam v. Kansas City S. Ry. Co., 635 F.3d 796, 803 (5th Cir. 2011) (finding the complete preemption doctrine is an "exception to the well-pleaded complaint rule").

101 14B WRIGHT, MILLER \& COOPER, supra note 11, $\$ 3722.2$.

102 Seinfeld, supra note 12, at 569. 
another perspective, the doctrine provides a "corollary" 103 to the well-pleaded complaint rule - that is, the doctrine merely "recharacterizes" state law claims as federal law claims if a federal statute broadly covers the subject matter. ${ }^{104}$

Although most perspectives address a particular test-the congressional intent test or the exclusive federal cause of action test-some perspectives address the doctrine as a whole. For instance, in one view, "Congress would do well to eliminate a doctrine that is contrary to sound jurisdictional theory, exceedingly difficult to apply, and the bane of judges and litigants alike."105 In another view, however, the doctrine rests on a solid rationale: it "unmask[s] federal claims masquerading as state ones."106

2. Perspectives on the Tests.

a. Views on the Congressional Intent Test. Although the Supreme Court created the exclusive federal cause of action test in 2003, some courts continue to apply the older congressional intent test. Few commentators, however, praise the congressional intent test. One scholar who favors the test asserted that it ensures that only a narrow class of situations constitute exceptions to the well-pleaded complaint rule, since the test requires that the court find that Congress intended to allow defendants to remove claims in the subject matter of the federal statute. ${ }^{107}$

Most views, however, criticize the congressional intent test for several reasons. ${ }^{108}$ One view holds that the Supreme Court jurisprudence establishing the congressional intent test sends "conflicting signals" 109 on the scope of the complete preemption doctrine and lacks a "principled analysis," 110 which creates confusion and different interpretations in the lower courts.111 The Supreme Court ostensibly failed to provide a systematic rationale and thus deprived the lower courts of comprehensible precedent.112 Further, the Court failed to evaluate the complete set of values that applies to removal, caused lower courts

103 See, e.g., Melchor v. Foster Poultry Farms, Inc., No. 1:12-CV-00339 AWIGS, 2012 WL 1836289 (E.D. Cal. May 21, 2012) (finding that "[c]omplete preemption ... is a corollary to the well-pleaded complaint rule").

104 McGreal, supra note 12, at 148.

105 Robert A. Ragazzo, Reconsidering the Artful Pleading Doctrine, 44 HASTINGS L.J. 273, 335 (1993).

106 Ennest A. Young, Stalking the Yeti: Protective Jurisdiction, Foreign Affairs Removal, and Complete Preemption, 95 CALIF. L. REV. 1775, 1814 (2007).

107 Helmer, supra note 70 , at 230.

108 Karen A. Jordan, The Complete Preemption Dilemma: A Legal Process Perspective, 31 WAKE FOREST L. REV. 927, 928 (1996); Tristin K. Green, Complete Preemption-Removing the Mystery from Removal, 86 CALIF. L. REV. 363, 376 (1998).

109 Jordan, supra note 108 , at 928.

110 Id. at 929 .

111 Id. at 928-29; Green, supra note 108, at 376.

112 Jordan, supra note 108 , at 964. 
to inconsistently apply the law, and prevented a principled perspective of the doctrine. ${ }^{113}$ Consequently, many lower courts oversimplified the doctrine. ${ }^{114}$ In short, although the Supreme Court stated that the test inquires into congressional intent, some commentators assert that the test did not help lower courts because the Court did not specify the amount of intent.115 Thus, courts too often allow removal, which increases the caseload of the federal court system and thereby reduces the quality of its output.116

b. Views on the Exclusive Federal Cause of Action Test. Consequently, some commentators prefer the exclusive federal cause of action test. Defenders of this test assert that it more clearly defines the complete preemption doctrine. ${ }^{117}$ The test requires that the federal statute expressly preempt state laws and substitute a federal remedy for that law. This arguably balances the wellpleaded complaint rule and ensures that plaintiffs do not improperly keep certain cases out of federal court.118 One supporter of the test argues that federal courts should decide some types of claims and that the test "makes things simpler, faster, [and] more efficient." ${ }_{119}$

Defender of the test claims that it benefits judicial economy and litigant resources.120 Another supporter claims that the test brings "clarity to the [complete preemption] doctrine."121 Moreover, the fact that the test limits complete preemption to federal statutes that provide a federal remedy arguably maintains the general quality of the federal courts. ${ }^{122}$

However, many criticize the test. Justice Scalia authored a dissent in Beneficial National Bank v. Anderson, where the court created the test. He asserted that the test does not justify an exception to the well-pleaded complaint rule and called the complete preemption doctrine a "federalize-and-remove dance."123 Other critics disapprove of the fact that the test permits removal "in any circumstance in which federal law provides someone a cause of action and

\footnotetext{
113 Id.

114 Green, supra note 108 , at 379.

115 Oleksandra Johnson, The Bankrupty Code as Complete Preemption: The Ultimate Trump?, 81 AM. BANKR. L.J. 31, 58 (2007).

116 Moss, supra note 26, at 1638.

117 See, e.g., Garrick B. Pursley, Rationalizing Complete Preemption After Beneficial National Bank v. Anderson: A New Rule, A New Justification, 54 DRAKE L. REV. 371 (2006) (asserting that the exclusive federal cause of action test "rehabilitates the hopelessly muddled complete preemption doctrine").

118 McGreal, supra note 12, at 149.

119 Pursley, supra note 117 , at 432.

$120 \mathrm{Id}$.

121 Seinfeld, supra note 12 , at 548.

122 Moss, supra note 26, at 1639.

123 Beneficial Nat'l Bank v. Anderson, 539 U.S. 1, 18 (2003) (Scalia, J., dissenting).
} 
also precludes state law causes of action."124 Still, others maintain that the test raises concerns because it expands federal jurisdiction and does not require "express congressional authorization." 125 Thus, the test fails to respect the autonomy of state courts and the tradition that only Congress has the power to limit this autonomy.126

Other perspectives assert that the exclusive federal cause of action test lacks a rationale.127 Under one view, the test lacks a coherent theory because the Supreme Court did not heed the basic principles that underlie federal question jurisdiction-that is, the "relationship between preemption, federal jurisdiction, and the interest in a uniform interpretation of federal law."128 Moreover, the test arguably lacks a rationale that addresses litigants' need to avoid state courts in some instances in order to "sidestep" state court bias.129 Another view asserts that the test fails to explain why an exclusive federal cause of action triggers complete preemption. ${ }^{130}$

Further, some commentators attack the mechanics of the exclusive federal cause of action test.131 Under this view, the test needs a criterion that expressly requires a "full substantive analysis to determine jurisdiction." As is, the test arguably impedes judicial efficiency. ${ }^{132}$ Detractors argue that the test lacks predictability and needlessly moves cases between state and federal courts. ${ }^{133}$

c. Improvements to the Tests. Naturally, scholars have suggested numerous ways to improve both the congressional intent test and the exclusive federal cause of action test. One scholar suggests amending the congressional intent test to allow complete preemption if the plaintiff attempts to manipulate the language in the state court complaint to avoid federal jurisdiction.134 Under another perspective, the congressional intent test simply needs a predictable, understandable, and usable framework. ${ }^{135}$

\footnotetext{
124 Miles v. Okun, 430 F.3d 1083, 1095 (9th Cir. 2005) (Berzon, J,, concurring in part and concurring in the result).

125 Johnson, supra note 115 , at 61.

126 Young, supra note 106, at 1819; Beneficial Nat'l Bank, 539 U.S. at 11-22 (Scalia, J., dissenting).

127 See Seinfeld, supra note 12, at 549; Morrison, supra note 18, at 189.

128 Seinfeld, supra note 12 , at 549.

129 Id. at 554.

130 Morrison, supra note 18 , at 189.

131 See, e.g., Margaret Tarkington, Rejecting the Touchstone: Complete Preemption and Congressional Intent After Beneficial National Bank v. Anderson, 59 S.C. L. REv. 225, 275 (2008).

$132 \mathrm{Id}$.

133 Id. at 294.

134 Moss, supra note 26, at 1602.

135 A. Mark Segret, The Federal Premption Question-A Federal Question? An Analysis of Federal Jurisdiction Over Supremacy Clause Issues, 33 CLEV. ST. L. REV. 653, 657 (1984).
} 
Similarly, the exclusive federal cause of action test arguably needs a bright line rule too. One perspective asserts that the exclusive federal cause of action test needs to limit complete preemption to situations in which the federal government has a strong interest in legislative uniformity. ${ }^{136}$

3. Complete Premption and the Copyright Act. Four circuits have already addressed whether the complete preemption doctrine applies to the Copyright Act; district courts in the remaining circuits need to decide whether to apply the congressional intent test or the exclusive federal cause of action test to determine if the doctrine applies to the Copyright Act, if they believe that the doctrine rests on solid footing. ${ }^{137}$ For example, the United States District Court for the District of New Mexico, located in the Tenth circuit, did not apply either test to the Copyright Act because the court rejected the doctrine on the grounds that the doctrine did not rest on solid footing. ${ }^{138}$

a. The Congressional Intent Test and the Copyright Act. The Congressional intent test causes a number of different outcomes in the copyright context. For example, in Rosciszenskiviv. Arete Associates, the Fourth Circuit applied the congressional intent test. ${ }^{139}$ The Court decided that Congress intended the Copyright Act to completely preempt state law claims because "Congress employed a broad mandatory preemption provision for causes of action equivalent to copyright claims" in section 301(a) ${ }^{140}$ of the Copyright Act and because Congress granted exclusive jurisdiction over copyright claims to the federal district courts in 28 U.S.C. $\$ 1338(a) .{ }^{141}$ Thus, the Court applied the complete preemption doctrine to the Copyright Act. ${ }^{142}$ Conversely, in American Airlines Inc. v. Biztraveldeals.com, the United States District Court for the Northern District of Texas, located in the Fifth Circuit, applied the congressional intent

\footnotetext{
136 Seinfeld, supra note 12 , at 573.

137 Rosciszewski, 1 F.3d at 232-33; Ritchie, 395 F.3d at 286-87; Briarpatch, 373 F.3d at 305; Tombs, 215 F. App'x at 82.

138 Black v. Kos, No. 05-163, 2005 WL 4564587, at *1 (D.N.M. Mar. 29, 2005).

139 Rosciszeuskei, 1 F.3d at 232.

140 Id.; 17 U.S.C. $\$ 301$ (a) (2006) ("On and after January 1, 1978, all legal or equitable rights that are equivalent to any of the exclusive rights within the general scope of copyright as specified by section 106 in works of authorship that are fixed in a tangible medium of expression and come within the subject matter of copyright as specified by sections 102 and 103, whether created before or after that date and whether published or unpublished, are governed exclusively by this title. Thereafter, no person is entitled to any such right or equivalent right in any such work under the common law or statutes of any State.").

14128 U.S.C. $\$ 1338$ (a) ("The district courts shall have original jurisdiction of any civil action arising under any Act of Congress relating to patents, plant variety protection, copyrights and trademarks ....").

142 Rosciszewski, 1 F.3d at 233.
} 
test but disagreed with the analysis in Rosciszewski..$^{143}$ The court held that $\$ \$ 1338(a)$ and 301(a) did not prove congressional intent to allow complete preemption in the Copyright Act context.144

b. The Exclusive Federal Cause of Action Test and the Copyright Act. Similarly, the exclusive federal cause of action test leads to varying results. In Briarpatch Ltd. v. Pboenix Pictures, Inc., the Second Circuit applied the exclusive federal cause of action test, which requires that the court find that the federal statute "both preempts state law and substitutes a federal remedy for that law, thereby creating an exclusive federal cause of action." 145 The Second Circuit decided that the Copyright Act creates an exclusive cause of action because the Act "lays out the elements, statute of limitations, and remedies for copyright infringement." 146 Conversely, in Board of Cbosen Freebolders v. Tombs, the Third Circuit applied the exclusive federal cause of action test and found that the Copyright Act did not provide an exclusive remedy. ${ }^{147}$

c. The Two-Prong Test of Subject Matter and General Scope. If the court applies either the congressional intent test or the exclusive federal cause of action test and decides that that test shows the Copyright Act so completely covers the field of copyright law that the complete preemption doctrine applies, then the court applies yet another test. ${ }^{148}$ This test consists of two prongs and determines whether the Copyright Act covers the specific subject matter of the plaintiff's state claim.149 "The first prong of the [two-part] test is known as the 'subject matter requirement,' and the second prong is known as the 'general scope requirement." "150 If the court finds that the two-part test shows that the Copyright Act does cover the specific subject matter of the state law claim, then the court holds that the defendant properly removed the case to federal court and denies the defendant's motion to remand.151

The subject matter prong "is satisfied if a work fits within the general subject matter of $\$ \$ 102$ and 103 of the Copyright Act, regardless of whether it qualifies for copyright protection."152 Specifically, the court must determine

\footnotetext{
143 No. 4:08-CV-069-A, 2008 WL 818536, at *3 (N.D. Tex. Mar. 26, 2008).

144 Id.

145 Briarpatch, 373 F.3d at 305.

146 Id.

147 Bd. of Chosen Freeholders v. Tombs, 215 F. App'x 80, 82 (3d Cir. 2006).

148 DowD, supra note 38, $₫ 10: 5$.

149 Id.

150 Id. (quoting Briarpatch, 373 F.3d at 305).

151 Id.

152 Stanford v. Caesars Entm't, Inc., 430 F. Supp. 2d 749, 755 (W.D. Tenn. 2006) (quoting Stromback v. New Line Cinema, 384 F.3d 283, 300 (6th Cir. 2004)).
} 
whether the Plaintiff's state law claim involves any of the following types of material:

(1) literary works;

(2) musical works, including any accompanying words;

(3) dramatic works, including any accompanying music;

(4) pantomimes and choreographic works;

(5) pictorial, graphic, and sculptural works;

(6) motion pictures and other audiovisual works;

(7) sound recordings;

(8) architectural works; [or]

(9) compilations or collections [of the above types of works]. ${ }^{153}$

In the second prong, the court assesses whether the state law right "is equivalent to any of the exclusive rights under $\ 106$ of the Copyright Act." 154 Section 106 grants copyright owners the exclusive rights to reproduce, derive, distribute, perform, and display copyrighted works. 155 Courts apply the "extra element test" to determine if the state law right "is equivalent" to any of these rights.156 In the extra element test, the court "must examine the elements of the state law claim":157

[T] $\mathrm{f}$ an extra element is required instead of or in addition to the acts of reproduction, performance, distribution or display in order to constitute a state-created cause of action... [and] the extra element changes the nature of the action so that it is qualitatively different from a copyright infringement claim, [then the state right in the state law claim] "is [not] equivalent" [to the rights in the Copyright Act].158

In sum, if the court finds that the state law claim involves the same type of material in $\int 102$ and 103 and finds that the state law claim requires proof of the same elements without requiring extra elements, then the court holds that

\footnotetext{
153 DowD, supra note $38, \$ 10.7 ; 17$ U.S.C. $\$ \$ 102-103$ (2006).

154 Stromback, 384 F.3d at 301.

15517 U.S.C. $\$ 106$ (2006)

156 Stanford, 430 F. Supp. $2 d$ at 757-58.

157 Chris-Leef Gen. Agency, Inc. v. Rising Star Ins. Inc., No. 11-cv-2409-JAR, 2011 WL. 5039141 , at *2 (D. Kan. Oct. 24, 2011).

158 Stanford, 430 F. Supp. 2d at 758 (quoting Stromback, 384 F.3d at 301).
} 
the Copyright Act covers the general subject matter of the state law claim and the defendant properly removed the state court case to federal court.159

d. The Results of the Two-Prong Test. The results of the two-prong test are unpredictable.160 Courts have applied the two-prong test to several state law claims. ${ }^{161}$ In some cases courts have found that the Copyright Act completely preempts and allows removal of the following state law claims:

[B]reach of implied contract, tortious interference with prospective economic advantage, breach of contract, deceptive trade practices, unjust enrichment/misappropriation/unfair competition, negligent failure to acknowledge one work is based on another, conversion, ... declaration of ownership of rights in a work, a claim for slander of title based on allegations of ownership, ... a right of publicity claim over use of a fictional character. ${ }^{162}$

Conversely, in other cases, courts have applied the two-prong test and held that the Copyright Act does not completely preempt and therefore does not allow removal of the following state law claims:

[B]reach of contract, tortious interference with prospective economic advantage, fraud and civil conspiracy, breach of fiduciary duty, breach of a confidential relationship, promissory estoppel, deceptive trade practices, misrepresentation, failure to pay royalties or to account for profits earned by a co-owner of the copyright, unfair competition/unjust enrichment/misappropriation, trade secret misappropriation, right of privacy, right of publicity, defamation, and conversion. 163

159 DowD, supra note $38, \llbracket 10.6$.

160 See, e.g., Patrick v. Francis, 887 F. Supp. 481, 484 (W.D. N.Y. 1995) (applying the two-prong test and finding that the Copyright Act preempted a conversional claim); County of Del. v. Gov't Sys., Inc., 230 F. Supp. 2d 592, 601-02 (E.D. Pa. 2002) (applying the two-prong test and finding that the Copyright Act did not preempt a conversion claim).

161 See, e.g., Krueger v. Tradeguider Sys., LLC, No. 07 C 6261, 2007 WL 4219194 (N.D. Ill. 2007 Nov. 27, 2007) (applying the two-prong test to a breach of contract claim); Firoozye v. Earthlink Network, 153 F. Supp. 2d 1115 (N.D. Cal. 2001) (applying the two-prong test to a misrepresentation claim); Tavormina v. Evening Star Prods., Inc., 10 F. Supp. 2d 729 (S.D. Tex. 1998) (applying the two-prong test to an unjust entichment claim).

1625 PATRY, supra note 44 , at 17-75 to -77 (citations omitted).

1635 id. at $17-73$ to -75 (citations omitted). 
e. Views on Complete Preemption in the Copyright Act Context. Critics of the complete preemption doctrine in the copyright context assert a number of views. Some commentators assert that complete preemption in the copyright context often leaves the plaintiff without a remedy. ${ }^{164}$ Others argue that Congress expressly provided for removal in various statutes but not in the Copyright Act because Congress did not intend to extend complete preemption to the Copyright Act. ${ }^{165}$ Further, some scholars criticize the extra element test; they assert that courts misconstrue the test and overlook the elements and instead scrutinize the underlying facts and wrongly assess if the facts give rise to a copyright claim. ${ }^{166}$ The Sixth Circuit has further identified additional problems with the extra element test:

The problem with this test is that it does not provide any real guidance to the courts. There is always some difference between the state law and the Copyright Act, so a court that wants to avoid preemption can always find some difference, however small, that is the 'extra element' needed to avoid preemption. ${ }^{167}$

A few scholars, however, defend complete preemption in the copyright context. For example, under one view the complete preemption doctrine provides a reasonable exception to the well-pleaded complaint rule. Indeed, in the copyright context, parties often assign and license rights in contracts, and the circumstances often involve significant federal interests. ${ }^{168}$

Commentators also offer various suggestions to improve the doctrine in the copyright context. In one view, courts simply need to rigorously apply the extra element test and focus on the elements of the state law cause of action, rather than the underlying facts. ${ }^{169}$ Moreover, the doctrine arguably needs a stronger standard to ensure that courts do not override the traditional values of jurisdiction. ${ }^{170}$

164 Helmer, supra note 70, at 217.

165 Amy J. Everhart, Ritchie v. Williams and the Complete Preemption Doctrine in Copyright: The New Federal/ State Debate, 42 TENN. B.J. 18, 22 (2006).

166 Helmer, supra note 70, at 209; see also Chris-Leef General Agency, Inc. v. Rising Star Ins. Inc., No. 11-cv-2409-JAR, 2011 WL 5039141, at *3 (D. Kan. Oct. 24, 2011) ("[A] defendant 'takes the wrong approach by focusing its preemption analysis on the conduct alleged'... the Court must 'compare the elements of the causes of action, not the facts pled to prove them." (quoting Harolds Stores v. Dillard Dep't Stores, 82 F.3d 1533, 1543 (10th Cir. 1996))).

167 Ritchie v. Williams, 395 F.3d 283, 291 (6th Cir. 2005) (quoting Schuyler Moore, Straightening Out Copyright Preemption, 9 UCLA ENT. L. REV. 201, 204 (2002)).

168 Id.

169 Helmer, supra note 70 , at 228.

170 Id. at 210. 


\section{NTD ARCHITECTS V. BAKER}

Applying the complete preemption doctrine in the copyright context presents a complex set of questions, and the recent case of NTD Architects $v$. Baker provides a rich background for evaluating the mechanics of the interplay of the doctrine and Copyright Act. ${ }^{171}$

\section{A. BACKGROUND}

In August 2011, NTD Architects, an architectural firm in San Diego, sued two former employee architects in San Diego Superior Court. ${ }^{172}$ In May 2011, Baker and Nowicki had formed their own architectural firm, Baker Nowicki Design Studio, and started to compete with NTD Architects. ${ }^{173}$ Both firms provided design services to large commercial development projects such as public schools. ${ }^{174}$ In state court, NTD Architects asserted that Baker and Nowicki stole property of NTD Architects when the two architects left NTD Architects to start Baker Nowicki Design Studio.175 Specifically, NTD Architects claimed that Baker and Nowicki stole photographs, drawings, computer files, project tracking forms, marketing plans, funding calculation forms, renderings, meeting minutes, models, documents, external computer drives, trade secrets, and a laptop computer. ${ }^{176}$

The complaint alleged eight causes of action under state law. ${ }^{177}$ Specifically, NTD Architects alleged breach of trust, conversion, breach of fiduciary duty, misappropriation of trade secrets, intentional interference with prospective economic advantage, unfair competition, breach of fiduciary duty, breach of a Nowicki employment contract, and breach of a Baker employment contract.178

In December 2011, NTD Architects filed a second lawsuit in the United States District Court for the Southern District of California against Baker and Nowicki. ${ }^{179}$ The complaint alleged the same underlying facts as the August 2011 complaint and asserted two cases of action: copyright infringement and false advertising. ${ }^{180}$ In January 2012, Baker and Nowicki removed the earlier case

171 NTD Architects v. Baker, No. 12-CV-0020-AJB-JMA, 2012 WL 2498868, at *1-8 (S.D. Cal. June 27, 2012).

172 Id. at $* 1$.

173 Id.

174 Id.

175 Id.

176 Id.

177 Id.

178 Id.

179 Id.

180 Id. 
from the San Diego Superior Court to the United States District Court for the Southern District of California on the grounds that the case involved copyrightprotected materials and raised issues of federal copyright law. ${ }^{181}$ In response, NTD Architects filed a motion to remand the case to state court. ${ }^{182}$

In the motion to remand, NTD Architects asserted that the state court complaint did not present questions of federal law and thus that the federal court did not have jurisdiction. ${ }^{183}$ Although NTD Architects noted that copyright law protected some of the stolen materials, its motion to remand stated, "[ $t$ ]his case has no business in federal court. Plaintiffs State Court Complaint is not a complaint based on copyright infringement, nor does it allege a cause of action for copyright infringement."184

Baker and Nowicki opposed the motion to remand, 185 arguing that the state court complaint did raise federal questions. ${ }^{186}$ Baker and Nowicki claimed that NTD Architect's motion to remand ignored the complete preemption doctrine and that the doctrine applied to the Copyright Act. ${ }^{187}$ Baker and Nowicki then described the two-prong test and argued that the state law claims satisfied the first prong of the test because NTD Architects admitted that copyright law covered the type of materials in the complaint.188 Baker and Nowicki then asserted that several of the claims satisfied the second part of the test.189 For example, Baker and Nowicki applied the extra element test to the conversion claim, then asserted that a conversion claim and a copyright claim of unauthorized reproduction have the same elements because both assert that the defendant unlawfully reproduced material. ${ }^{190}$

The United States District Court for the Southern District of California first considered the complete preemption doctrine in the context of the Copyright Act. ${ }^{191}$. The court noted that federal courts have jurisdiction to hear federal question cases and that the complete preemption doctrine provides a

181 Id. at $* 2$.

182 Id.

183 Plaintiff's Memorandum of Point and Authorities in Support of Motion to Remand to State Court Pursuant to 28 U.S.C. $\$ 1447$ (c) at 1-2, NTD Architects v. Baker, No. 12-CV-0020-AJBJMA (S.D. Cal. Feb. 3, 2012).

184 Id. at 1.

185 Defendants' Opposition to Plaintiff's Motion to Remand to State Court Pursuant to 28 U.S.C. $\int 1147$ (c), NTD Architects v. Baker, No. 12-CV-0020-AJB-JMA at 1-22 (S.D. Cal. Feb. $22,2012)$.

186 Id. at $9-10$.

187 Id. at $10-12$.

188 Id. at 12-14.

189 Id. at $14-19$.

$190 \mathrm{Id}$.

191 NTD Arcbitects, 2012 WL 2498868, at *4. 
"corollary" that allows federal courts to also hear cases that involve state law. ${ }^{192}$ However, the complete preemption doctrine applies to only a "handful" of statutes. 193 The court identified two Supreme Court cases in which the Court. focused on the intent of Congress as its basis for extending the complete preemption doctrine to the Labor Management Relations Act and the Employee Retirement Security Act. ${ }^{194}$ The Southern District of California court also found "[i]n evaluating whether...the Copyright Act qualifies ... the decision by the U.S. Court of Appeals for the Fourth Circuit in Rosciszenskiv. Arete Associates ... [was] particularly instructive," 195 especially as it too focused on the intent of Congress when it extended complete preemption to the Copyright Act. 196

The Fourth Circuit in Rosciszweski focused on two statutory provisions to evaluate congressional intent. ${ }^{197}$ The court stated, "[i]n the Fourth Circuit's view, two statutory provisions demonstrated Congress's intent to completely preempt state copyright law: the Act's preemption provision, 17 U.S.C. \$ 301 (a), and the jurisdictional statute relating to copyright actions, 28 U.S.C. $\$ 1338(a) . " 198$ First, the court followed the analysis of the Fourth Circuit and noted the broad nature of the preemption provision in $\$ 301$ (a). ${ }^{199}$ The court agreed with the Rosciszueski court that the broad nature of the provision showed that "Congress has clearly indicated that state law claims which come within the subject matter of copyright law and which protect rights equivalent to any of the exclusive rights within the scope of federal copyright law... should be litigated only as federal copyright claims."'200 Second, the court considered $\$ 1338(a)$ and agreed with the Fourth Circuit that "the grant of exclusive original jurisdiction over copyright claims to the district courts [provides] strong evidence that Congress intended copyright litigation to take place in federal courts."201 Thus, the court concluded that the complete doctrine applied to the Copyright Act. ${ }^{202}$

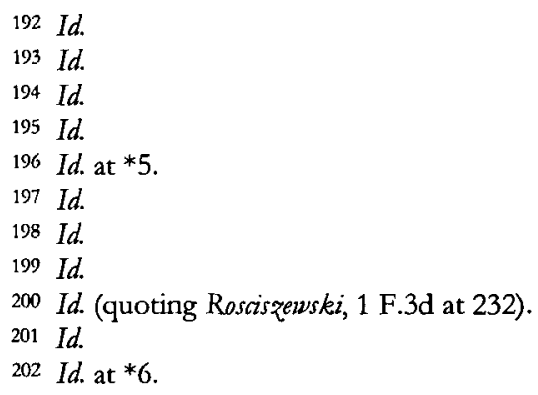


Next, the court applied the two-prong test. ${ }^{203}$ First, the court determined that the types of materials referred to by the complaint-the external hard drives, trade secrets, and other materials-constituted the types of materials in $\iint 102$ and 103 of the Copyright Act, which lists literary works and architectural works, among others. The court held that the physical objects-the laptop computer, external hard drives, and other objects-qualified as copyrighted materials and that NTD Architects admitted that copyright protected the materials. ${ }^{204}$ Thus, these materials in the complaint satisfied the first prong of the test. ${ }^{205}$ Second, the court found that the extra element test showed that a conversion claim required essentially the same elements. ${ }^{206}$ The court stated, "[t]o state a claim for conversion under California law, a plaintiff must establish: (1) the plaintiffs ownership or right to possession of a certain piece of property; (2) the defendant's conversion of the property by a wrongful act or disposition of property rights; and (3) damages." 207 The court noted that "[t]o some degree, a claim for conversion has an extra element beyond the Copyright Act, since the plaintiff is required to prove that the defendant wrongfully obtained possession over the specific piece of property." 208 Nonetheless, the court ultimately concluded that a claim of conversion did not require an extra element and that "just one claim is sufficient to warrant removal"; the court ruled that the remaining seven state law claims required an extra element.209

\section{B. ANALYSIS OF THE DECISION}

The decision of the United States District Court for the Southern District of California to allow Baker and Nowicki to remove the case raises a number of issues.

1. The Complete Premption Doctrine. The court decided that the complete preemption doctrine rests on solid footing, but other jurisdictions disagree. ${ }^{210}$ Although the court concluded that jurisprudence on the doctrine shows that it applies to only a "handful" of statutes, the court determined that the doctrine rests on sufficiently solid footing to apply to the Copyright Act.211 The court cited two Supreme Court cases that additionally applied the doctrine to the

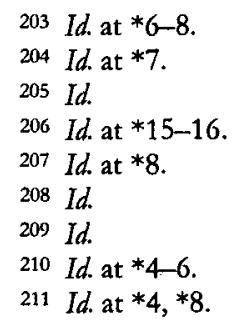


Labor Management Relations Act and the Employee Retirement Income Security Act.212 In Black v. Kos, however, the United States District Court for the District of New Mexico declined to consider the complete preemption doctrine in the context of the Copyright Act because " $t]$ he Supreme Court has not spoken on the issue, nor has a clear consensus emerged among the circuits."213 Thus, the United States District Court for the District of New Mexico did not apply the congressional intent test or the exclusive federal cause of action test. ${ }^{214}$ Moreover, one commentator who considered the complete preemption doctrine stated, "Congress would do well to eliminate a doctrine that is contrary to sound jurisdictional theory." 215 Thus, the court potentially leapt to an unjustified decision to consider the doctrine.

2. The Congressional Intent Test and the Exclusive Federal Cause of Action Test. Courts apply either the congressional intent test or the exclusive federal cause of action test. ${ }^{216}$ The United States District Court for the Southern District of California applied the congressional intent test without considering the exclusive federal cause of action test. ${ }^{217}$ Although the district court noted the decisions of the Supreme Court in Arco and Taylor, in which the Court created the congressional intent test, the district court did not note the Supreme Court's decision in Anderson, in which the Court created the exclusive federal cause of action test. ${ }^{218}$ The Court decided Taylor in 1987 and Anderson in 2003.219 Many commentators assert that the Anderson decision overrides Taylor such that the exclusive federal cause of action test supplants the congressional intent test. ${ }^{220}$ Nonetheless, among the four circuits where the Courts of Appeals have decided whether the complete preemption doctrine applies to the Copyright Act, only three decisions occurred after 2003.221 One court still applied the congressional intent test, but two courts adopted the exclusive federal cause of action test to assess whether the complete preemption doctrine applied to the Copyright

\footnotetext{
212 Id.

213 No. CIV 05-163, 2005 WL 4564587, at *2.

214 Id.

215 Ragazzo, supra note 105 , at 335.

216 NTD Architects v. Baker, No. 12-CV-0020-AJB-JMA, 2012 WL 2498868, at *4-5 (S.D. Cal. June 27, 2012).

217 See Metro. Life, 481 U.S. at 61-67; Beneficial Nat'l Bank, 539 U.S. at 8-11.

218 Beneficial Nat'l Bank, 539 U.S. at 8-11.

219 Id.; Taylor, 481 U.S. at 66-67.

220 See Tarkington, supra note 131, at 227; Helmer, supra note 70, at 220.

221 Ritchie v. Williams, 395 F.3d 283, 286-87 (6th Cir. 2005); Briarpatch Ltd. v. Phoenix Pictures, Inc., 373 F.3d 296, 305 (2d Cir. 2004); Bd. of Chosen Freeholders v. Tombs, 215 F. App'x 80, 82 (3d Cir. 2006).
} 
Act.222 Further, in recent district court decisions, many courts have still applied the congressional intent test. 223

Nonetheless, the court arguably misapplied the jurisprudence of the Supreme Court in the area of complete preemption. The court did not acknowledge the Anderson decision, which established the exclusive federal cause of action test, and instead relied on the pre-Anderson Rosciszewski decision, where the Fourth Circuit utilized the congressional intent test to assess complete preemption in the context of the Copyright Act.224 If the court needed persuasive authority on complete preemption in the Copyright Act context, then the decisions of the Second and Fifth Circuits in Briarpatch and Board of Chosen Freebolders provide recent post-Anderson analyses of complete preemption and the Copyright Act, where the courts applied the exclusive federal cause of action test.225

Furthermore, although courts still apply the congressional intent test, many commentators criticize the test. ${ }^{226}$ The decision of the NTD court to apply the congressional intent test arguably creates a vague precedent because the test does not specify the amount of congressional intent, lacks a systematic rationale, and potentially increases the caseload of the federal courts. ${ }^{227}$ Indeed, in this case, the caseload of the federal courts increased because the court denied the motion to remand.

Ultimately, the court concluded that the congressional intent test showed that the complete preemption doctrine applies to the Copyright Act, but the court did not address counterarguments that the test does not show that the complete preemption doctrine applies to the Copyright Act.228 For example, in Briarpatch, the Second Circuit stated, "[u]ntil the Supreme Court's recent

222 Ritchie, 395 F.3d at 286-87 (applying the federal cause of action test); Briarpatch, $373 \mathrm{~F} .3 \mathrm{~d}$ at 305 (applying the exclusive federal cause of action test); Tombs, 215 F. App'x at 82 (applying the exclusive federal cause of action test).

223 See Main \& Assocs., Inc. v. Blue Cross \& Blue Shield of Ala., 776 F. Supp. 2d 1270, 1277 (M.D. Ala. 2011).

224 NTD Architects, 2012 WL 2498868, at *4-5.

225 Briarpatch, 373 F.3d at 305; Tombs, 215 F: App'x at 82.

226 See Jordan, supra note 108, at 964 ("The [Supreme] Court's failure to systematically engage in reasoned elaboration has deprived the lower courts of understandable and guiding precedent.'); Green, supra note 108, at 379 ("While some circuits have salvaged a coherent doctrine of complete preemption... others have settled upon an overly-simplified understanding of preemption as a basis for removal.").

227 See Johnson, supra note 115, at 58 (asserting that the congressional intent test did not help lower court because the Supreme Court did not specify the amount of intent); Moss, supra note 26, at 1638 (asserting that the complete preemption doctrine increased the case load of federal courts); Jordan, supra note 108, at 964 ("The [Supreme] Court's failure to systematically engage in reasoned elaboration has deprived the lower courts of understandable and guiding precedent.").

228 NTD Architects, 2012 WL 2498868, at *5-6. 
decision in [Anderson] ... we would have hesitated to extend the complete preemption doctrine into the copyright field." 229 The Second Circuit continued, "[a]lthough the Fourth Circuit had extended the complete preemption doctrine to ... the Copyright Act [in Roscisqewskl], the point was debatable."230 Thus, the Second Circuit questioned the Rosciszewski decision and doubted that the congressional intent test showed that the complete preemption doctrine applied to the Copyright Act.231. In NTD, the court relied on Rascizeweski, where the Fourth Circuit applied the congressional intent test and found the doctrine applied to the Copyright Act.232 The court did not consider counterarguments. ${ }^{233}$

Specifically, the court cited Roscizeweski and asserted that $\$ 301$ (a) of the Copyright Act suggested that Congress intended to allow the complete preemption doctrine to apply to the Copyright Act, ${ }^{234}$ but other commentators have disagreed with the NTD court by asserting that $₫ 301$ does not evidence congressional intent. 235 For instance, in Cambridge Library Properties, Ltd. $v . W$. Goebel Porzellanfabrik G.m.b.H. \& Co., Judge Cyr of the First Circuit of Appeals wrote a dissenting opinion that raised the issue of complete preemption and compared section 301(b) to the Employee Retirement Security Act (ERISA).236 The Supreme Court subsequently held that the complete preemption doctrine applied to ERISA.237 Judge Cyr noted that $\$ 1144(\mathrm{a})$ of ERISA states that ERISA "shall supersede any and all State" laws." 238 Conversely, $\$ 301$ (b) of the Copyright Act states that "[n]othing in [the Copyright Act] annuls or limits any rights or remedies under the common law or statutes of any State," which suggests that Congress did not intend the Act to broadly cover state law claims that tangentially relate to copyright law. ${ }^{239}$ Moreover, one commentator asserted that Congress expressly included provisions on removal in other statutes but did not include a provision on removal in the Copyright Act.240

3. The Two-Prong Test of Subject Matter and General Scope. The NTD Architects court potentially made an unwarranted local leap as well in the first prong of the

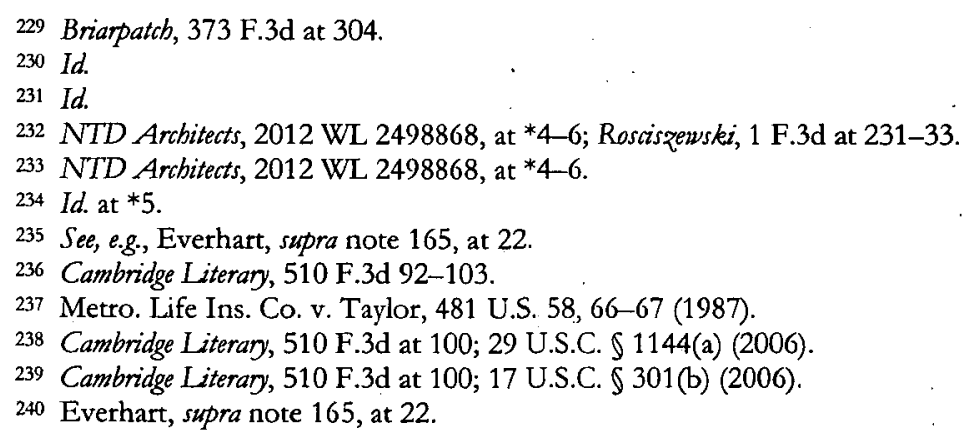


two-prong test. The court concluded that $\$ \$ 102$ and 103 of the Copyright Act cover the types of materials in the state court complaint-computer files, external hard drives, and other materials. ${ }^{241}$ However, the court did not describe the nature of the files or the contents of the hard drives. ${ }^{242}$

Similarly, in the second prong of the two-prong test, the court provided a somewhat vague analysis of the extra element test. ${ }^{243}$ The court observed that "[t]o some degree[] a claim for conversion has an extra element beyond the Copyright Act[] since the plaintiff is required to prove that the defendant wrongfully obtained possession over the specific piece of property."244 However, the court paradoxically concluded that a conversion claim does not contain an extra element. ${ }^{245}$ This reasoning lacks consistency. While some cases find that conversion contains an extra element, ${ }^{246}$ and others do not, ${ }^{247}$ the court did not consider any of these cases. Moreover, the court allowed Baker and Nowicki to remove their case to federal court on the slimmest of margins-the court found that each of the other seven claims contained an extra element.248

\section{UNANSWERED QUESTIONS}

The NTD Arcbitects decision in particular and the jurisprudence of the complete preemption doctrine in the copyright context in general leave many unanswered questions. First, the District Court for the Southern District of California did not explain why seven of NTD Architects' claims contained an extra element, and the omission glares because the court granted removal of the entire case on the ground that the one claim of conversion did not contain an extra element. ${ }^{249}$ Why. does a breach of contract claim contain an extra element? Why does a misappropriation of trade secrets claim contain an extra element? The NTD Architects court noted that some courts find that a breach of contract

\footnotetext{
241 NTD Architects, 2012 WL 2498868, at *7.

242 Id.

243 Id. at *7-8.

244 Id. at $* 8$.

245 Id.

246 E.g., Asunto v. Shoup, 132 F. Supp. 2d 445, 452-53 (E.D. La. 2000) (finding that a conversion claim contains an extra element); County of Del. v. Gov't Sys., Inc., 230 F. Supp. 2d $592,601-02$ (finding that a conversion claim contains an extra element).

247 See Dielsi v. Falk, 916 F. Supp. 985, 992 (C.D. Cal. 1996) (finding that a conversion claim does not contain an extra element); Patrick v. Francis, 887 F. Supp. 481, 484 (W.D.N.Y. 1995) (finding that a conversion claim does not contain an extra element).

248 NTD Arcbitects, 2012 WL 2498868, at *8.

249 Id.
} 
claim contains an extra element, ${ }^{250}$ and it declined to consider decisions where courts found that a breach of contract claim does not contain an extra element. Practitioners ought to look to these cases to bolster their arguments.

Second, the NTD Architects court did not acknowledge the exclusive federal cause of action test and offers no guidance on this opinion. Practitioners ought to argue that one test applies and shows that the complete preemption doctrine extends or does not extend to the Copyright Act.

Third, the NTC Architects court concluded that 17 U.S.C. $\$ 301$ (a) and 28 U.S.C. 1338(a) show that Congress intended to allow the complete preemption doctrine to apply to the Copyright Act,251 but the court did not consider that $\$ 301(b)$ states "[n]othing in ... [the Copyright Act] annuls or limits any rights or remedies under the common law or statutes of any State."252 Congress limited the scope of the Copyright Act in $\$ 301(\mathrm{~b}) .^{253}$ Section 301(b) helps practitioners who seek to argue that Congress did not intend the Copyright Act to cover state law claims that barely relate to copyright law-that is, Congress did not intend the complete preemption doctrine to apply to the Copyright Act.

\section{CONCLUSION}

Although NTD Architects v. Baker leaves many unanswered questions, the case highlights the fact that plaintiffs prefer state courts and defendants prefer federal courts. It also illustrates that practitioners capable of arguing the pros and cons of the complete preemption doctrine in general, and the doctrine in the copyright context in particular, enjoy greater success in removing a case to federal court or remanding a case to state court. NTD Architects filed their case in state court and presumably felt more comfortable in that venue. The architectural firm perhaps hoped to avoid the bias of federal courts, which often favor defendants. Naturally, Baker and Nowicki transferred the case to federal court, as statistics show that defendants fare better in federal court. ${ }^{254}$ Although the District Court for the Southern District of California held that the complete preemption doctrine applies to the Copyright Act,255 many commentators dislike the complete preemption doctrine either as a whole or one of its two tests, while others argue that the doctrine simply does not apply

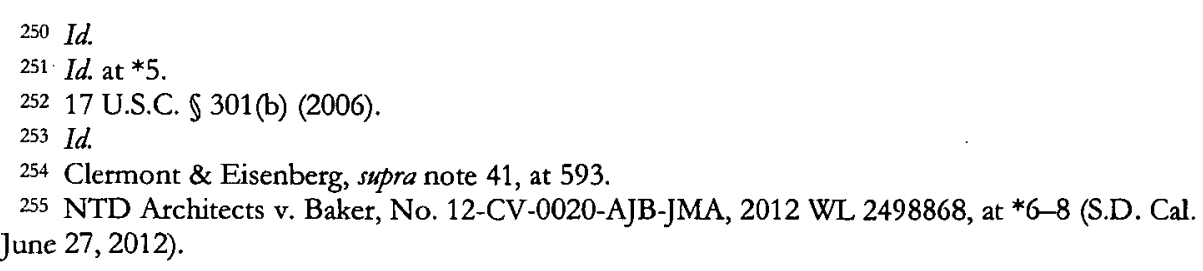


in the copyright context.256 Informed practitioners use these competing perspectives to bolster their arguments.

In most circuits, courts grapple to apply or reject the complete preemption doctrine in the copyright context. ${ }^{257}$ Thus, the analysis of the decision in NTD Architects empowers practitioners and courts to evaluate the doctrine. The complete preemption doctrine in general, the congressional intent test, the exclusive federal cause of action test, and the two-prong test each provide separate fora of battle.

256 See Seinfeld, supra note 12, at 548-49; Morrison, supra note 18, at 186-94; Helmer, supra note 70 , at $223-29$.

257 See, e.g., Chris-Leef Gen. Agency v. Rising Star Ins., No. 11-cv-2409-JAR, 2011 WL 5039141, at *3 (D. Kan. Oct. 24, 2011) (observing that "most district courts within the Tenth Circuit inconsistently apply the [complete preemption] doctrine to the Copyright Act"). 